\title{
HUKUM PERDAGANGAN DALAM EKONOMI ISLAM
}

\author{
Mushawwir Hasbi \\ Perbankan Syariah \\ Fakultas Ekonomi dan Bisnis Islam \\ UNIVERSITAS ISLAM NEGERI ALAUDDIN MAKASSAR \\ Mushawwir230901@gmail.com
}

Tujuan ekonomi Islam kini banyak diperkenalkan sebagai salah satu alternatif atas sistem ekonomi yang telah banyak digunakan di seluruh dunia. Sistem ekonomi Islam merupakan sebuah istilah di dalam Agama Islam untuk menjelaskan serangkaian proses aktivitas manusia di dalam perdagangan.

Sekarang,banyak lembaga ekonomi yang telah berupaya untuk menerapkan prinsip dan tujuan ekonomi Islam di dalam kegiatan jual beli. Hal ini tak lain bertujuan untuk menyediakan proses perputaran ekonomi yang aman dan sesuai dengan ajaran Agama Islam di dalam Alquran. Namun di balik semua hal tersebut, masih banyak yang tak mengetahui secara pasti mengenai prinsip, kelebihan, hingga tujuan ekonomi Islam yang diterapkan. Maka dari itu, tak ada salahnya untuk mengetahui dan mempelajari lebih lanjut mengenai tujuan ekonomi Islam tersebut.

Mari kita lihat prinsip hingga tujuan ekonomi Islam yang berhasil dirangkum dari berbagai sumber berikut ini.

\section{a. Konsep Ekonomi Islam}

Dilansir dari laman Nahdlatul Ulama ( NU ), ekonomi Islam seperti yang tertuang pada buku Al-Iqtishad Al-Islamy: Madkhal wa Manhaj karya Dr. Asyraf Muhammad Dawabah secara lebih rinci merupakan suatu sistem alternatif atas sistem ekonomi yang hingga saat ini masih dipergunakan yakni kapitalis dan sosialis. 
Istilah ekonomi Islam pada dasarnya masih terbilang baru dalam sistem ekonomi di dunia. Meskipun kemunculannya tidak dapat disebut baru yakni pada pertengahan abad dua puluh. Kendati demikian, secara tidak langsung praktik dan tujuan ekonomi Islam pada dasarnya sudah diterapkan sejak kemunculan Agama Islam di dunia.

Di dalam buku tersebut dijelaskan bahwa kedua sistem ekonomi terbesar di dunia tengah mengalami keruntuhan. Sejak saat itulah kemudian para ilmuwan Islam mulai menggetolkan pemahaman mengenai prinsip-prinsip ekonomi Islam sebagai suatu solusi.Secara garis besar, ekonomi Islam memiliki kelebihan yang tak terdapat di kedua sistem ekonomi tersebut. Baik kapitalisme maupun sosialisme, keduanya memiliki kelemahan yang dapat diatasi saat suatu perdagangan menerapkan ekonomi Islam.

\section{b. Prinsip Dasar Ekonomi Islam}

Selain memiliki kelebihan dan tujuannya, ekonomi Islam juga diperkenalkan dengan beberapa prinsip. Beberapa prinsip tersebut di antaranya adalah adanya dualisme kepemilikan, kebebasan ekonomi yang teratur, dan adanya tanggung jawab sosial. Berikut penjelasan selengkapnya mengenai ketiga prinsip ekonomi Islam tersebut :

\section{Dualisme Kepemilikan}

Dalam Agama Islam rupanya mengakui kepemilikan pribadi dan kepemilikan umum secara bersamaan. Hal ini lah yang tidak terdapat pada kedua sistem ekonomi besar di dunia sehingga secara tidak langsung ekonomi Islam merupakan solusi atas permasalahan kedua sistem ekonomi tersebut. Secara lebih lanjut, hak kepemilikan pribadi tersebut tidak lantas membebaskan penggunanya. Kegiatan jual beli tetaplah harus dilakukan secara wajar dan tidak berlebih-lebihan.

\section{Kebebasan Ekonomi yang Teratur}

Ekonomi Islam sebenarnya tidak terlalu mengikat, sebab Allah SWT menjamin kebebasan dan ruang gerak ekonomi manusia seluas-luasnya. Dalam hal tersebut dapat 
dimaknai bahwa jaminan kebebasan dalam menjalankan kegiatan ekonomi tersebut haruslah sesuai dengan syariat dan nilai-nilai Agama Islam.

\section{Tanggung Jawab Sosial}

Prinsip yang terakhir adalah adanya tanggung jawab sosial. Tanggung jawab sosial inilah yang seharusnya banyak dilakukan oleh para pelaku ekonomi. Sebab, dengan melakukan serangkaian tanggung jawab sosial maka secara langsung dirinya juga telah bersedekah terhadap sesama. Hal inilah yang diajarkan oleh Agama Islam.

c. Kelebihan ekonomi Islam

Penerapan Ekonomi Islam disebut akan lebih sempurna apabila dilakukan dengan baik dan sesuai dengan syariat Islam. Apabila tidak diterapkan dengan sempurna, maka sistem ekonomi Islam tersebut tidak akan jauh berbeda dengan sistem ekonomi konvensional yang ada yakni kapitalisme dan sosialisme. Maka dari itu, penerapannya akan jauh lebih baik apabila pelaku ekonomi memahami secara lebih lanjut mengenai kelebihan ekonomi Islam. Beberapa kelebihan dari ekonomi Islam tersebut antara lain sebagai berikut :

\section{Adanya Moral dan Etika}

Dalam ekonomi Islam, penggunanya secara tidak langsung akan dihadapkan dengan serangkaian moral dan etika. Dalam Islam, konsumsi tidak hanya mementingkan aspek kepuasan materi, melainkan juga lebih cenderung untuk pemenuhan kebutuhan. Saat melakukan jual beli, Islam juga mengajarkan beberapa norma yang seharusnya ditaati oleh pelaku ekonomi.

\section{Keadilan Dalam Proses Distribusi}

Sistem ekonomi Islam juga menjadikan keadilan sebagai suatu asas yang harus dipenuhi saat melakukan perdagangan. Islam juga memberikan batasan-batasan dalam distribusi fungsional agar tercipta kestabilan dalam kesejahteraan ekonomi yang diharapkan. Hal 
tersebut jelas berbeda dengan prinsip kapitalisme yang cenderung menimbulkan kesenjangan, begitu pula dengan sosialisme yang cenderung menikmati kemiskinan secara bersama-sama.

\section{Sistem Pemaukan yang Aman}

Kelebihan yang terakhir dari ekonomi Islam adalah adanya sistem pemasukan yang cukup berbeda dari sistem ekonomi konvensional. Pemasukan tersebut yakni berdasarkan aktivitas yang menghasilkan laba dan modal. Maka dari itu, tujuan ekonomi Islam tersebut juga berhasil yakni menghilangkan sistem bunga hingga adanya penghasilan tetap dari berjalannya suatu aktivitas ekonomi.

Daftar Pustaka :

AZ Darussalam, A. M.-A. (2017). Konsep perdagangan dalam ekonomi Islam ulama indonesia. J.Sidabalok. (2020). Hukum Perdagangan nasional dan perdagangan internasioanal. 